\title{
UM TIPO DE MÁGICA: ASPECTOS DA RIMA EM POEMAS ORIGINAIS E TRADUZIDOS
}

\author{
A KIND OF MAGIC: ASPECTS OF THE RHYME IN ORIGINAL AND \\ TRANSLATED POEMS
}

Alípio Correia de FRANCA NETO*
Universidade de São Paulo, Brasil

Resumo: Rimas em poemas originais e traduzidos são o tema deste artigo, seu objetivo sendo analisá-las como cerceamentos potencialmente criativos na escrita original e na tradução. Com esse objetivo, o artigo analisa ideias comumente aceitas sobre rimas, como a suposição de que rimas limitam a expressão, para refutá-las por meio de argumentos girando em torno ao potencial criativo das rimas em poemas originais e em poemas traduzidos, rimas sendo consideradas como convenções ou cerceamentos que, uma vez usadas com propriedade pelo poeta e pelo poeta-tradutor, são um componente da sua originalidade. Desse ângulo, o uso apropriado da rima estaria ligado à criação de contextos logicamente convincentes para as rimas. No caso de traduções poéticas, em que o tradutor não pode senão usar um contexto estrangeiro como ponto de partida para a experiência literária a ser desenvolvida em sua tradução, o contexto estrangeiro é já um cerceamento a mais no caso de rimas, o que prova que os cerceamentos na tradução são maiores do que na escrita original. Essas ideias sobre rima também são apresentadas no artigo como relacionadas a visões pessoais do autor sobre tradução poética, inspiradas por escritos críticos de Jean Boasse-Beier e Michael Hamburger. Segundo os pontos de vista do autor, seguindo os passos de Jean BoasseBeier, a tradução é uma arte cerceada, e "paráfrases poéticas", que ele define idiossincraticamente a partir de suas elaborações das idéias seminais de Dryden sobre o assunto, é o expediente que ele escolhe para lidar com cerceamentos na tradução poética. Por fim, o artigo analisa trechos da tradução de O flautista em Hamelin à luz dessas idéias, e inclui uma versão atualizada do poema publicado em décadas anteriores.

Palavras-chave: Rima. Tradução. Poesia. Paráfrase poética. Robert Browning.

\begin{abstract}
Rhymes in original and translated poems are the subject of this article. Its aim is to analyze them as potentially creative constraints in original poems and poetic translations. So, the article analyzes commonly accepted ideas about rhymes, such as the assumption that rhymes limit expression, in order to refute them by means of arguments revolving around the creative potential of rhymes in original poems and translated ones, rhymes being considered as conventions or constraints that, once they are used properly by the poet and the poettranslator, are a component of their originality. From this angle, the proper use of rhyme is related to the creation of logically convincing contexts for rhymes. In the case of poetic translations, in which the translator can only use a foreign context as a starting point for the literary experience to be developed in his translation, the foreign context itself is already an extra contraint when rhymes are involved, which proves that constraints in translation are bigger than those ones in original writing. These ideas about rhyme are also presented in the article as being related to the author's personal views about poetic translation, ones inspired by critical writings by Jean BoasseBeier and by Michael Hamburger. According to the author's views, following Jean Boasse-Beier's steps, translation is a constrained art, and "poetic paraphrases", which he defines idiosyncratically from his developments of Dryden's seminal ideas on the subject, is the way he chooses to deal with constraints in poetic translation. At last, the article analyzes passages from the translation of The Pied Piper of Hamelin in the light of these ideas, and includes an updated version of the poem published in previous decades.
\end{abstract}

Keywords: Rhymes. Translation. Poetry. Poetic paraphrase. Robert Browning. 
RECEBIDO EM: 23 de janeiro de 2019

ACEITO EM: 20 de fevereiro de 2019

PUBLICADO EM: julho 2019

s palavras que se seguem se ocupam de aspectos da rima quer em poemas originais
quer em poemas traduzidos, examinando pontos de vista contemporâneos sobre
rimas, efeitos causados por elas e critérios de pertinência em uso, meus argumentos convergindo em particular para a ideia de que rimas, como outras convenções, são cerceamentos à escrita e à tradução, e de "paráfrases poéticas", conforme as defino aqui e em outros escritos a partir de elaborações de ideias seminais de Dryden, me parecem uma alternativa, em termos de busca de equivalências, que encontro em face de problemas tradutórios complexos. Como exemplo de minha abordagem, apresento ao fim do artigo minha tradução de O Flautista de Manto Malhado em Hamelin, de Robert Browning, numa versão nova, embora preservando longas sequências de versões publicadas em 1994 e em 2010¹.

Entre nós, de vez em quando se ouve falar que a "poesia moderna" teria deixado de rimar, o que por si mesmo seria uma prova de que a poesia em geral, afinal de contas, não precisa rimar para ser poesia.

Essa suposição costuma vir acompanhada de justificativas, parecendo ditadas por uma crença em algo como um "decoro poético" da época, e segundo as quais efeitos de "continuidade", "consonância" e "totalidade" associados a rimas estariam em descompasso com uma "sensibilidade da época", depois que a literatura e as artes, por inúmeras razões, e há muito conhecidas, se empenharam tanto em causar justamente efeitos contrários de "descontinuidade", "fragmentação" ou "dissonância", por exemplo, aparentemente mais condizentes com os tempos. Além do mais, quando a ideia de "razão" deixou de exercer efeitos "universalizantes", ou num mundo marcado pelo individualismo e busca da "expressão pessoal", rimas não pareceriam "razoáveis" por darem a impressão de uma excessiva racionalidade envolvida em sua constituição, ou por representarem riscos de efeitos estéticos indesejáveis, como impressões ocasionais de "previsibilidade", condução "mecânica" da experiência poética e de função meramente "ornamental", ou, no nível da criação, o risco de desvios nocionais de alguma lógica interior perseguida pelo poeta, o que talvez seja responsável 
pela ideia de que, por implicar tais complexidades, rimas, ou até versos métricos, acabariam por "limitar" a expressão poética. Devido a argumentos como esses, que fazem a rima parecer anacrônica, "artificial”, até mesmo um obstáculo desnenessário à criação poética, tende-se a supor que uma postura contrária a elas se apoie em bases racionais mais sólidas.

É possível, porém, fazer várias objeções a cada uma dessas ideias. A primeira é que, para se encontrar uma "prova" de que rimas nunca foram indispensáveis à poesia, basta lembrar a de culturas de várias épocas e lugares em que rimas não foram usadas²

A objeção seguinte diz respeito ao fato de técnicas e temas específicos traírem um compromisso com ideias modernistas e serem apresentados como categorias de valoração ainda hoje. Que sentido haveria em fazer isso? ? $^{\text {. }}$

Outras objeções, de ordem técnica e relativas aos efeitos de rimas mencionados, é que rimas também foram e são empregadas com efeitos de "descontinuidade", "dissonância" ou “incompletude" em diversas literaturas ao longo da história até os dias de hoje, e contrariamente a seus usos tradicionais ${ }^{4}$. Um lance de olhos, por exemplo, a muitos autores contemporâneos ingleses e americanos, considerados pertencentes ao que se pode chamar de mainstream, se valem de rimas, seu reconhecimento público como grandes poetas por vezes convivendo com o de também serem "artistas da rima" - um dado capaz de revelar a fragilidade de generalizações do tipo "a poesia moderna deixou de rimar", e de nos fazer lembrar que a poesia, a mais antiga e universal das artes, sempre seguiu e seguirá em direções imponderáveis.

A objeção final diria respeito não propriamente à ideia de que rimas são "cerceamentos", "obstáculos" no processo de escrita, mas à consideração de que seu uso limitaria de alguma forma a expressão poética. Para explicar isso, convém examinar em que consistiria esse "obstáculo" da rima.

Tomadas em si mesmas, rimas são, em termos estritos, nonsense $e^{5}$. Uma rima é a simples combinação de palavras por similidade de som. Uma rima é uma rima, independentemente de quaisquer nexos semânticos entre as palavras que rimam. "Notas"/ "remotas", "vulto"/ "tumulto" preenchem os requisitos para ser considerados rimas perfeitas, e, mesmo que fosse possível inferir relações de sentido entre as palavras, isso não importaria para que fossem considerados assim. De modo que é em torno desse núcleo desprovido de significação das rimas que o poeta espera tecer uma rede de sentido plausível e a partir dos fios de palavras as interligando: 
E se ouve um som, mal soa três notas,

De tropas múrmuras, remotas;

E o murmúrio vira um tumulto;

E o tumulto então toma vulto;

O que quer dizer que os "sentidos" adquiridos pelas palavras que rimam não se acham nelas mesmas, mas no contexto que lhe é criado: só esse contexto pode conferir sentido às relações não-lógicas de som entre os pares de rima. Assim, rimas são de fato um cerceamento exterior para o escritor, imposto por convenções que o leitor partilha com ele, e que são "regras" segundo as quais se dá o "jogo da rima”, o escritor esperando do leitor, além da consciência da convenção, a impressão de que ele a esteja usando com pertinência. À nossa sensibilidade atual, infensa a usos retóricos obsoletos em nossas tradições literárias, essa impressão de pertinência se liga à percepção de que as rimas ocorrem segundo o desenvolvimento lógico do pensamento, de que elas são uma consequência disso, e, portanto, sua recorrência dá a impressão de se dar, por assim dizer, por "serendipismo". Quando isso ocorre, a fruição genuína por parte do leitor advém de sua consciência de um pleno domínio técnico (afinal de contas, poesia é uma criação voluntária, não produto de "geração espontânea"), ou, o que é o mesmo, de uma consciência de que o poeta "superou um obstáculo" e de que o poema continuou preservando, ou desenvolvendo, sua poeticidade. Dessa ótica, esquemas rímicos, a exemplo de outras convenções, tem o condão de potencializar ${ }^{7}$ a experiência poética justamente pela expectativa inerente dos riscos que envolvem. Por outro lado, o processo criativo também pode envolver ocasionalmente uma impressão de "serendipismo" durante a busca de rimas, quanto esta enseja a percepção e escolha de palavras novas e surpreendentes, que o poeta talvez não fizesse sem esses cerceamentos específicos, e em virtude da descoberta de dimensões de sentido ricas e até então insuspeitas. Otávio paz:

Inclinado sobre sua mesa, os olhos fixos e vazios, o poeta-que-não-crê-na-inspiração já terminou sua primeira estrofe, segundo o plano previamente traçado. Nada foi deixado ao acaso. Cada rima e cada imagem tem a necessidade rigorosa de um axioma, tanto quanto a gratuidade e a leveza de um jogo geométrico. Contudo, está faltando uma palavra para arrematar o hendecassílabo final. O poeta consulta o dicionário em busca da rima rebelde. Não consegue encontrá-la. Fuma, levanta-se, senta-se, torna a se levantar. Nada: vazio, esterilidade. E de repente aparece a rima. Não a esperada, mas outra - sempre outra - completa a estrofe de modo imprevisto e talvez contrário ao projeto original. Como explicar essa colaboração? (PAZ, 1982, p. 192). ${ }^{8}$ 
A julgar por essas palavras, em vez de "limitações" à critatividade, cerceamentos à escrita como rimas podem vir a ser uma fonte para ela, e também o que lhe permite assumir riscos. Por outro lado, a se pesar bem, a suposição inicial de rimas limitando a expressão já não fazia sentido, já que, a rigor, não pode haver escrita sem cerceamentos, e toda criação literária original sofre cerceamentos advindos das suas próprias tradições literárias ${ }^{9}$.

Váléry disse que os poetas trabalhavam com a dificuldade da língua, não contra ela; Pound, que ninguém andava com desenvoltura enquanto não aprendesse a "lidar com grilhões"; e Larkin, que arte era lutar contras as artificialidades da arte. Para uma teórica como Jean Boasse-Beier, por exemplo, a escrita original é cerceada por coisas tão diversas quanto visões políticas predominantes, características linguísticas do meio (como, por exemplo, palavras "que rimam e outras não" num poema sendo escrito), regras estilísticas ou mesmo a sintaxe, que determinam a ordem das orações, os tipos de concordância. Diz a teórica:

[...] os escritores originais não escrevem simplesmente o que querem: são limitados por toda a sorte de cerceamentos: políticos, sociais, poéticos e linguísticos, bem como os cerceamentos do próprio texto, o que cria um contexto, potencialmente limitando e determinando a forma e o sentido de cada expressão. (BOASE-BEIER, 2016, p. 9).

Rimas são uma manifestação de qualidades poéticas, não uma qualidade em si, e, se usadas com propriedade, resultam também num poema, por assim dizer, como Fiona Samson disse uma vez, com a "coragem de suas convicções". Quando rimas não dão a impressão de suceder segundo um desenvolvimento espontâneo do pensamento, por causa de inversões canhestras, ou quando chamam demais a atenção para si mesmas ${ }^{11}$, o contexto gerador de relações lógicas para as rimas é perturbado, e elas se tornam um expediente "mecânico", apenas um "tinido" se prolongando em virtude de seu próprio eco.

Como uma modalidade de escrita, tradução é uma arte essencialmente "cerceada". Escolho traduzir assim a frase "constrained art", uma definição dada por Jean Boasse-Beier e da qual me valho ${ }^{12}$, além do aparato conceitual da Estilística Cognitiva, da Linguística Cognitiva e da Teoria da Relevância, para fornecer uma visão de um “jogo" pessoal de tradução poética e formular "regras" para uso próprio ${ }^{13}$, que acredito usar coerente e consecutivamente em traduções poéticas e que coincidem com minhas conceitualizações de "paráfrase poética", a partir de reflexões sobre Dryden e sobre os escritos críticos e a própria prática tradutória de Michael Hamburger. Foge ao escopo dessas palavras esmiuçar tais ideias aqui, mas, em termos de uma visão pessoal de tradução poética, ou do que posso esperar de uma, seu êxito depende, grosso modo, de uma crença da parte do leitor (que também poderíamos chamar de "crítico da 
tradução") de que a tradução logrou exprimir "valores cognitivos" discernidos como leituras possíveis do original, valores por sua vez sempre materializados na escrita por meio das escolhas pessoais do tradutor e reconhecidos concomitantemente como "intenção" do tradutor/autor inferido pelo tradutor e pelo crítico de tradução, essa mesma tradução de valores cognitivos sendo sentida pelo crítico de tradução como a superação de uma "dificuldade" e suscitando a "ilusão" de um "universal" no produto final da tradução, ou a ilusão de uma "paridade", "equivalência" em algum nível, entre o texto-fonte e o texto-alvo. Dessa mesma impressão de "superação de cerceamentos", pois, adviria o "prazer" do "jogo da tradução poética", e o estabelecimento de seu status de obra provida de autonomia e integridade, não mais "inferior" ao original em decorrência de sua suposta "intraduzibilidade"14. Por outro lado, no que tange a "paráfrases poéticas", talvez seja suficiente dizer que a experiência tradutória deve se dar dentro do que se possa considerar como "latitudes", coincidindo com limites interpretativos, e, que nesse "jogo" da paráfrase poética me é peritido não seguir as palavras do autor "tão estritamente quanto seu sentido, que também pode ser ampliado, mas não alterado"15.

Essas ideias estão por trás da tradução de The pied piper of Hamelin, de Robert 232 Browning, escolhido aqui como exemplo de um poema desafiante em particular no que diz respeito a tentativas de mimetização de idiossincrasias de rimas e esquemas rímicos complexos, chegando a incorporar longas sequências de versos arrematados pela mesma rima.

Falar em termos de uma "mimetização" do texto poético pode dar a impressão de que se trata de um processo de escrita do texto-alvo incorporando valores cognitivos relativos a som e sentido a cada gesto poético interpretado no texto-fonte. Não se devem esquecer, porém, os cerceamentos advindos da tradição literária do texto-alvo, responsáveis por afastamentos voluntários na tradução quanto a valores cognitivos. Dois exemplos extraídos da tradução bastam para explicar como isso ocorre:

An hour they sat in council,

At length the Mayor broke silence:

"For a guilder I'd my ermine gown sell,

"I wish I were a mile hence!

Minha versão semântica:

Por uma hora se sentaram em conselho.

Por fim, o Alcaide quebrou o silêncio: 
-- por um florim eu minha toga de arminho venderia,

Quem me dera estar a uma milha daqui!

Traduzi o terceiro verso lhe conservando intencionalmente a inversão da ordem da frase (“I'd my gown sell"), que coincide com a "rima em mosaico", e que soa drástica não só aos ouvidos de um inglês contemporâneo, mas também na época de Browning, um mestre da rima que aqui faz uso de semelhante inversão para conferir um tom alambicado à fala do Alcaide, ao mesmo tempo que corteja o riso do leitor infantil, com seu gosto por rimas. Do ponto de vista da língua-alvo, preservar esse valor cognitivo - a inversão da ordem da frase - soaria intolerável poeticamente, por influência do que consideramos ultrapassado em nossa tradição. Em todo caso, minha versão da passagem reescreve as "rimas em mosaico", mas procura lhes resguardar a poeticidade, purgando o terceiro verso da inversão:

Uma hora de conselho. Enfim o

Alcaide quebra o gelo, e diz:

- Vendo a um florim o meu arminho;

Quem dera estar bem longe, edis!

Diga-se que a palavra "edis", aqui, é minha solução para "Corporation” [Corporação\}, com seus "vereadores", e esse acréscimo, segundo minhas propostas de paráfrase, coincide com a ideia de Dryden de uma "ampliação" de sentido, sem "alterá-lo" (no contexto do poema, os “edis" estão presentes).

No exemplo seguinte,

And, whether they pipe us free from rats or from mice, If we've promised them aught, let us keep our promise!,

que traduzo semanticamente como

e, se eles [os flautistas] com a flauta nos livarem dos camundongos, se lhes tivermos prometido algo, cumpramos nossas promessas! 
Eu poderia escolher mimetizar a imperfeição da rima ("from mice/promise") mais ou menos assim,

Se ele der fim a tais desgraças

Pra nós, cumpramos as promessas!,

mas minha opção pelas rimas perfeitas,

Se ele extinguir pragas como essas

Pra nós, cumpramos as promessas!,

leva em conta nosso rimalho tradicional em poemas infantis, em que rimas com diferença vocálica, como "desgraças" e "promessas", são muito incomuns, além de exigir um esforço interpretativo ou um conhecimento técnico improvável da parte do público infantojuvenil a que minha tradução essencialmente se destina.

A par de sua memoralidade (um atributo da poesia a que ninguém se oporia), rimas complementam ritmos, e suscitam uma fruição psicologicamente difícil de analisar e que as faz parecer, como Anne Sexton se referia a seus poemas métricos e rimados, um tipo de "mágica" - aliás, a mais atrativa em nossa infância, quando adorávamos "brincar com o som".

\section{Robert Browning}

\section{I}

\section{The pied piper of Hamelin}

Hamelin Town's in Brunswick, By famous Hanover city; The river Weser, deep and wide, Washes its wall on the southern side; A pleasanter spot you never spied; But, when begins my ditty, Almost five hundred years ago, To see the townsfolk suffer so From vermin, was a pity.

II.

Rats!

They fought the dogs and killed the cats, And bit the babies in the cradles,

\section{O flautista de Manto Malhado em Hamelin}

Hamelin fica em Brunswick -- junto

A Hanover, célebre -- e é pequena.

O Weser, fundo e colossal,

Banha a porção meridional;

Você não viu um lugar igual!

Mas, começando a cantilena,

Há já quase quinhentos anos,

Ver cidadãos sofrendo os danos

Da peste, Ah!, dava tanta pena...

II

Ratos!

Mordiam cães, matavam gatos! 
And ate the cheeses out of the vats, And licked the soup from the cooks' own ladles,

Split open the kegs of salted sprats, Made nests inside men's Sunday hats, And even spoiled the women's chats By drowning their speaking With shrieking and squeaking In fifty different sharps and flats.

III

At last the people in a body

To the Town Hall came flocking:

"Tis clear," cried they, "our Mayor's a noddy;

"And as for our Corporation---shocking.

"To think we buy gowns lined with ermine

'For dolts that can't or won't determine

"What's best to rid us of our vermin!

'You hope, because you're old and obese,

"To find in the furry civic robe ease?

"Rouse up, sirs! Give your brains a racking

"To find the remedy we're lacking,

"Or, sure as fate, we'll send you packing!"

At this the Mayor and Corporation

Quaked with a mighty consternation.

IV

An hour they sat in council,

At length the Mayor broke silence:

"For a guilder I'd my ermine gown sell,

"I wish I were a mile hence!

"It's easy to bid one rack one's brain---

"I'm sure my poor head aches again,

"I've scratched it so, and all in vain.

"Oh for a trap, a trap, a trap!"

Just as he said this, what should hap

At the chamber door but a gentle tap?

"Bless us," cried the Mayor, "what's that?"

(With the Corporation as he sat,

Looking little though wondrous fat;

Nor brighter was his eye, nor moister

Than a too-long-opened oyster,
Nos bebezinhos davam botes!

Comiam queijo sobre os pratos!

Lambiam sopa nos seus potes!

Roubavam peixe ao roer caixotes!

Faziam ninhos em sapatos

De homens! e estragavam pacatos

Colóquios de mulher, com o ruído

De grito e de grunhido

Em mil bemóis e sustenidos e vibratos.

III

Por fim, o povo foi às portas

Da Prefeitura: -- Nosso Alcaide

É um tolo! E os seus edis, idiotas!

Pensar que nós pagamos - ai de

Nós! - o arminho que ele veste,

Pra não haver ninguém que preste,

Que possa nos livrar da peste!

Então o arminho, bando beócio,

É pra vocês viverem no ócio?

Se mexam! Dêem à bola uns tratos

E achem a solução pros ratos,

Ou vão pra rua, seus ingratos! --

O Alcaide e seus edis fiéis

Tremeram da cabeça aos pés.

IV

Uma hora de conselho. Enfim o

Alcaide quebra o gelo, e diz:

-- Vendo a um florim o meu arminho;

Quem dera estar bem longe, edis!

"Dar tratos à bola", ora, essa!

Já dói tanto a minha cabeça...

Não adiantou, coçá-la à beça;

Ai, eu com uma ratoeira agora! --

Depois dessa, o que esperar, fora

Um toc-toc-toc de leve fora?

-- Deus!, diz o Alcaide - o que é isso?,

Sentado com os edis, no início

Parece miúdo -- e bem roliço;

Olhos sem brilho, e com o aspecto

Viscoso de um marisco aberto,

-- Mas não se a pança, em alvoroço, 
Save when at noon his paunch grew mutinous

For a plate of turtle green and glutinous)

"Only a scraping of shoes on the mat?

"Anything like the sound of a rat

"Makes my heart go pit-a-pat!"

V

"Come in!"----the Mayor cried, looking bigger:

And in did come the strangest figure!

His queer long coat from heel to head

Was half of yellow and half of red,

And he himself was tall and thin,

With sharp blue eyes, each like a pin,

And light loose hair, yet swarthy skin,

No tuft on cheek nor beard on chin,

But lips where smiles went out and in;

There was no guessing his kith and kin:

And nobody could enough admire

The tall man and his quaint attire.

Quoth one: "It's as my great-grandsire,

"Starting up at the Trump of Doom's tone,

"Had walked this way from his painted tombstone!"

\section{VI}

He advanced to the council-table

And, "Please your honours," said he,

'I'm able,

"By means of a secret charm, to draw

"All creatures living beneath the sun,

"That creep or swim or fly or run,

"After me so as you never saw!

"And I chiefly use my charm

"On creatures that do people harm,

"The mole and toad and newt and viper;

"And people call me the Pied Piper."

(And here they noticed round his neck

A scarf of red and yellow stripe,

To match with his coat of the self-same cheque;

And at the scarf's end hung a pipe;

And his fingers, they noticed, were ever straying

As if impatient to be playing

Upon this pipe, as low it dangled
Quer Tartaruga -- um caldo grosso!

-- Só alguém que limpa o seu sapato

$\mathrm{Na}$ esteira? A um som que lembre um rato

Meu coração dispara no ato!

V

Entre! - ele parece maior;

E entra um sujeito assustador!

Seu manto, amarelo e vermelho,

Caía do ombro ao tornozelo;

O moço mesmo era alto e esguio,

O olhinho, azul e luzidio,

Cabelo longo, ar juvenil,

De barba, mesmo, nem um fio;

$\mathrm{Na}$ boca, um riso fugidio;

Parentes? Nunca ninguém viu.

O grupo olhava ali pasmado

O jovem tão mal-ajambrado;

Um disse: -- é como se um finado

No dia do Juízo Final

Viesse da cova a este local!

VI

Vai até à mesa do conselho:

-- Perdão, Excelência, - diz -- pelo

Encanto em minha flauta, eu guio

Tudo o que há sob o sol, rasteje

Ou ande ou corra ou nade ou voeje

De um modo como ninguém viu!

Sempre uso tais encantações

Contra toupeiras e tritões,

Sapos e cobras; sou chamado

Flautista de Manto Malhado

(E todos reparam, então,

Na echarpe, rubra e amarelada

Como o manto, e de igual padrão;

$\mathrm{Na}$ ponta, a flauta pendurada.

Os dedos dele, sem cessar

Se mexem, com ânsias de tocar

A flauta, a balançar à roda

Das vestes, tão fora de moda.) 
Over his vesture so old-fangled.)

"Yet," said he, "poor piper as I am,

"In Tartary I freed the Cham,

"Last June, from his huge swarms of gnats;

"I eased in Asia the Nizam

"Of a monstrous brood of vampyre-bats:

"And as for what your brain bewilders,

"If I can rid your town of rats

"Will you give me a thousand guilders?"

"One? fifty thousand!"---was the exclamation

Of the astonished Mayor and Corporation.

VII

Into the street the Piper stept,

Smiling first a little smile,

As if he knew what magic slept

In his quiet pipe the while;

Then, like a musical adept,

To blow the pipe his lips he wrinkled,

And green and blue his sharp eyes twinkled,

Like a candle-flame where salt is sprinkled;

And ere three shrill notes the pipe uttered,

You heard as if an army muttered;

And the muttering grew to a grumbling;

And the grumbling grew to a mighty rumbling;

And out of the houses the rats came tumbling.

Great rats, small rats, lean rats, brawny rats,

Brown rats, black rats, grey rats, tawny rats,

Grave old plodders, gay young friskers,

Fathers, mothers, uncles, cousins,

Cocking tails and pricking whiskers,

Families by tens and dozens,

Brothers, sisters, husbands, wives---

Followed the Piper for their lives.

From street to street he piped advancing,

And step for step they followed dancing,

Until they came to the river Weser,

Wherein all plunged and perished!

---Save one who, stout as Julius Csar,
-- Pobre flautista, nesse afã,

Na Tartária, cacei pro Chã

Pernilongos e carrapatos;

Na Ásia, vampiros, pro Nizã;

Quanto ao que os deixa estupefatos:

Se eu desse cabo dessa praga,

Livrando a cidade dos ratos,

Dariam mil florins em paga?

-- Só mil? Damos cinqüenta mil! -

Pasmado, o grupo redarguiu.

\section{VII}

Vai pro meio da rua. De início,

Sorri de forma bem discreta,

Como se ciente do feitiço

Que dorme em sua flauta quieta;

E como quem é um mestre nisso,

Franze a boca, a pupila cheia

Do verde-azul que se incendeia

No sal lançado a uma candeia;

E se ouve um som, mal soa três notas,

De tropas múrmuras, remotas;

E o murmúrio vira um tumulto;

E o tumulto então toma vulto;

Das casas, ratos saem num surto!

Mirrados, miúdos; corpulentos,

Grandes; pardos, pretos, cinzentos;

Jovens aos pulos, em seguida,

Velhinhos trôpegos, mães, pais

Penteando a suíça, e a cauda, erguida,

Em grupos de dez, doze ou mais!

Tios, primos, netos vão também

Seguindo-o para o próprio bem.

E rua a rua, ele, tocando,

E passo a passo, eles, dançando,

Chegam às margens do rio Weser,

Onde perecem, submersos;

Só um rato, um bravo Júlio César,

Cruza esse rio, levando intato

(Como o outro) um comentário em versos:

À Ratolândia o seu relato, 
Swam across and lived to carry (As he, the manuscript he cherished)

To Rat-land home his commentary:

Which was, "At the first shrill notes of the pipe,

"I heard a sound as of scraping tripe,

"And putting apples, wondrous ripe,

'Into a cider-press's gripe:

"And a moving away of pickle-tubboards,

"And a leaving ajar of conservecupboards,

"And a drawing the corks of train-oilflasks,

"And a breaking the hoops of buttercasks:

"And it seemed as if a voice

"(Sweeter far than b harp or b psaltery

"Is breathed) called out, 'Oh rats, rejoice!

"'The world is grown to one vast drysaltery!

“'So munch on, crunch on, take your nuncheon,

“'Breakfast, supper, dinner, luncheon!'

"And just as a bulky sugar-puncheon,

"All ready staved, like a great sun shone

"Glorious scarce an inch before me,

"Just as methought it said, 'Come, bore me!'

"---I found the Weser rolling o'er me."

\section{VIII}

You should have heard the Hamelin people

ringing the bells till they rocked the steeple.

"Go," cried the Mayor, "and get long poles,

"Poke out the nests and block up the holes!

"Consult with carpenters and builders,

"And leave in our town not even a trace

"Of the rats!"---when suddenly, up the face

Of the Piper perked in the market-place,

With a, "First, if you please, my thousand guilders!"
Que era, "a uma nota com estridor,

Som de raspar tripa; de pôr

Maçã madura - ai, que sabor! --

Pra fazer cidra num moedor;

Tirar tampa em tina; abrir portas

De armários cheios de compotas,

E cascos com óleo de baleia,

$\mathrm{E}$ frascos com manteiga e aveia;

Como se uma voz, mais sonora

Do que harpa ou saltério, também

Dissesse: "Ó ratos! Farra agora!

O mundo é um enorme armazém!

Belisquem, encham o bucho, eia!

Café e almoço e lanche e ceia!"

Quando a cuba de açúcar, cheia

De furos, como um sol, chispeia

Bem pertinho de mim - assim

Que julgo ouvir 'vem, entre em mim!' -

O Weser rolou sobre mim'.

VIII

As torres tremem sob o abalo

Do toque forte do badalo.

Diz o Alcaide: -- Catem ancinhos,

Cubram tocas, cutuquem ninhos,

Chamem o mestre-carpinteiro

E o arquiteto, não deixem pista

Dos ratos! - e eis que salta à vista,

Na praça, o rosto do Flautista,

Que diz: -- Meus mil florins primeiro! - 
IX

A thousand guilders! The Mayor looked blue;

So did the Corporation too.

For council dinners made rare havoc

With Claret, Moselle, Vin-de-Grave,

Hock;

And half the money would replenish

Their cellar's biggest butt with Rhenish.

To pay this sum to a wandering fellow

With a gipsy coat of red and yellow!

"Beside," quoth the Mayor with knowing wink,

"Our business was done at the river's brink;

"We saw with our eyes the vermin sink,

"And what's dead can't come to life, I think.

"So, friend, we're not the folks to shrink

"From the duty of giving you something for drink,

"And a matter of money to put in your poke;

"But as for the guilders, what we spoke

"Of them, as you very well know, was in joke.

"Beside, our losses have made us thrifty.

"A thousand guilders! Come, take fifty!"

\section{$\mathbf{X}$}

The Piper's face fell, and he cried

"No trifling! I can't wait, beside!

"I've promised to visit by dinnertime

"Bagdat, and accept the prime

"Of the Head-Cook's pottage, all he's rich in,

"For having left, in the Caliph's kitchen,

"Of a nest of scorpions no survivor:

"With him I proved no bargain-driver,

"With you, don't think I'll bate a stiver!

“And folks who put me in a passion

"May find me pipe after another fashion."

XI

"How?" cried the Mayor, "d'ye think I brook
IX

Os mil florins! Que ar infeliz

Têm esse Alcaide e os seus edis!

Reuniões causaram dano grave

No Hock, Moselle, Claret, Vin-de-Grave,

E com a metade desses mil

Se enchia de Reno um bom barril.

Pagar tanto a um pé-de-chinelo

Com manto vermelho e amarelo?

O Alcaide pisca com ar gaiato:

$a$-- O rio não consta em nosso trato;

Vimos afundar cada rato;

Mortos não voltam - acho. O fato

É que estou feliz, filho. E grato;

Quero brindar, e de imediato

Pôr-lhe uns trocados na algibeira;

Quanto aos florins... Não é que eu queira

Desapontar... Foi brincadeira!

A nossa perda foi violenta..

Mil florins? Vem, toma cinqüenta!

$\mathrm{X}$

Descai o rosto do rapaz:

-- Sem lérias! Tenho pressa, aliás;

Vou ter com o cuca num jantar

Em Bagdá, pra um caldo sem par,

Todo um banquete, por dar fim a

Escorpiões pela cozinha

Do Califa -- um ninho inteiro!

Ele não é um barganheiro;

Eu não lhe abato o meu dinheiro!

E quando fico insatisfeito,

Eu toco a flauta - de outro jeito!

XI

-- Como é que é? - o Alcaide retruca Me pondo abaixo desse cuca?, 
"Being worse treated than a Cook?

"Insulted by a lazy ribald

"With idle pipe and vesture piebald?

"You threaten us, fellow? Do your worst,

"Blow your pipe there till you burst!"

\section{XII}

Once more he stept into the street

And to his lips again

Laid his long pipe of smooth straight cane;

And ere he blew three notes (such sweet

Soft notes as yet musician's cunning

Never gave the enraptured air)

There was a rustling that seemed like a bustling

Of merry crowds justling at pitching and hustling,

Small feet were pattering, wooden shoes clattering,

Little hands clapping and little tongues

240 chattering,

And, like fowls in a farm-yard when barley

is scattering,

Out came the children running.

All the little boys and girls,

With rosy cheeks and flaxen curls,

And sparkling eyes and teeth like pearls,

Tripping and skipping, ran merrily after

The wonderful music with shouting and laughter.

XIII

The Mayor was dumb, and the Council stood

As if they were changed into blocks of wood,

Unable to move a step, or cry

To the children merrily skipping by,

---Could only follow with the eye

That joyous crowd at the Piper's back.

But how the Mayor was on the rack,

And the wretched Council's bosoms beat,

As the Piper turned from the High Street

To where the Weser rolled its waters

Right in the way of their sons and daughters!
Um vagabundo de um fedelho

De manto amarelo e vermelho?

Ameaças, hein? Pois vá tocar

Sua flauta - até se arrebentar!

\section{XII}

Vai para a rua uma vez mais

E leva à boca a flauta, feita

De bambu, bem lisa e direita;

Mal soam três notas (magistrais,

Cuja magia suave e terna

Nenhum mestre logrou jamais)

Se ouve um som brando, o som de um bando

Que chega aos trancos, tropeliando,

E se atropela, saltarela,

Com palmas, berra e tagarela;

E, aves à cata de quirela,

Surgem crianças em baderna,

Todos meninos e meninas,

Rostos rosados, tranças finas,

Dentes de pérola - traquinas,

O bando corre, empurra, esbarra

Ao som da flauta e em algazarra.

XIII

O Alcaide cala; o grupo queda

Como se transmudado em pedra,

Não dão nem mesmo um passo ou gritam

Para as crianças que saltitam -

Sem poder fazer nada as fitam

Atrás do moço sorrateiro.

O Alcaide fica em desespero

E os seus edis se sentem mal

Quando, da rua principal,

Vão pro Weser, a poucas milhas,

Seus queridos filhos e filhas!

Porém viram do sul para o oeste, 
However be turned from South to West, And to Koppelberg Hill his steps addressed,

And after him the children pressed;

Great was the joy in every breast.

"He never can cross that mighty top!

"He's forced to let the piping drop,

"And we shall see our children stop!"

When, lo, as they reached the mountainside,

A wondrous portal opened wide,

As if a cavern was suddenly hollowed;

And the Piper advanced and the children

followed,

And when all were in to the very last,

The door in the mountain-side shut fast.

Did I say, all? No! One was lame,

And could not dance the whole of the way;

And in after years, if you would blame

His sadness, he was used to say,---

"It's dull in our town since my playmates

left!

"I can't forget that I'm bereft

"Of all the pleasant sights they see,

"Which the Piper also promised me.

"For he led us, he said, to a joyous land,

"Joining the town and just at hand,

"Where waters gushed and fruit-trees grew

"And flowers put forth a fairer hue,

"And everything was strange and new;

"The sparrows were brighter than peacocks here,

"And their dogs outran our fallow deer,

"And honey-bees had lost their stings,

"And horses were born with eagles' wings:

"And just as I became assured

"My lame foot would be speedily cured,

"The music stopped and I stood still,

"And found myself outside the hill,

"Left alone against my will,

"To go now limping as before,

"And never hear of that country more!"

XIV

Alas, alas for Hamelin!

There came into many a burgher's pate
Ao Koppelberg; direto pra este

Ele anda, atrás, o bando investe;

Parece dádiva celeste!

-- Não passa da montanha alta;

Logo ele solta aquela flauta

E as crianças vão voltar, sem falta! -

Chegando à encosta, se repara

Numa porta, que se escancara,

Como se fosse uma caverna;

Ele entra, e os bandos em baderna;

Com todos lá, para o remate,

Aquela porta enorme bate.

Eu disse "todos"? Me esqueci do

Manco que ficou pra trás;

Depois, quando era repreendido

Por seu ar triste, esse rapaz

Sempre dizia: -- Tudo aqui

Ficou sem graça; eu perdi

A terra linda que eles veem,

A mim prometida também;

Terra entrevista, num relance,

Junto à cidade, ao nosso alcance,

Com suas fontes, frutas, aves

E flores de matizes suaves,

E coisas novas, admiráveis;

Com cães que correm mais que gamos;

Pardais que brincam entre os ramos

E são mais belos que pavões;

Abelhas que não têm ferrões;

Cavalos com asas. Ao ter fé

De achar a cura para o pé,

Cessou a música sonora,

E ali fiquei, a sós, de fora,

Ainda mancando, como agora,

Longe de tudo o que eu mais quis,

Sem saber mais desse país!

XIV

Ai, Hamelin, que pesadelo!

Um texto veio a entrar por fim 
A text which says that heaven's gate Opes to the rich at as easy rate As the needle's eye takes a camel in! The mayor sent East, West, North and South,

To offer the Piper, by word of mouth, Wherever it was men's lot to find him, Silver and gold to his heart's content, If he'd only return the way he went, And bring the children behind him. But when they saw 'twas a lost endeavour, And Piper and dancers were gone for ever,

They made a decree that lawyers never Should think their records dated duly If, after the day of the month and year, These words did not as well appear, "And so long after what happened here "On the Twenty-second of July, "Thirteen hundred and seventy-six:" And the better in memory to fix The place of the children's last retreat,
Na cuca de um burguês ruim; Um rico entra no céu assim Como, na agulha, entra um camelo!

Um núncio aos quatro cantos voa

Pra dar ao Flautista, em pessoa, Sempre que alguém julgasse vê-lo, Prata e ouro, o quanto lhe agradasse, A fim de que ele retornasse Com a criançada em atropelo.

Crendo-se vãos esforços tais O grupo ali não volta mais -Os documentos oficiais

Não têm valor, se se omitiu

$\mathrm{Na}$ data, por esquecimento,

Após dia e ano, o complemento:

"Passados tantos dias do evento

De Vinte e Dois de Julho em Mil

Trezentos e Setenta e Seis"

E pra memorizar de vez

A rua em que a leva foi vista

Chamam-na "Rua do Flautista"

(Ali, quem quer que seja pego

Com flauta perde logo o emprego).

Nem há estalagem nem taverna, Em rua tão séria, inoportunas; Mas, diante de onde está a caverna, Gravam essa história em colunas E a pintam nos vitrais da igreja, Para que todo o mundo veja Como sofreu o povo pacato; E o registro está lá, intato; Convém não omitir o fato De que uma tribo esquisita,

Of alien people who ascribe

The outlandish ways and dress

On which their neighbours lay such stress, To their fathers and mothers having risen Out of some subterraneous prison Into which they were trepanned Long time ago in a mighty band Out of Hamelin town in Brunswick land, But how or why, they don't understand.
Na Transilvânia, diz, convicta, Que herdou seus trajes e usos vivos (Mas muito estranhos aos nativos) De pais vindos em caravana De uma prisão subterrânea Aonde alguém os guiou, outrora, Por persuadi-los a ir-se embora De Hamelin, em Brunswick; da história, Porém, como, ou por que, se ignora. 
XV

So, Willy, let me and you be wipers

Of scores out with all men---especially

pipers!

And, whether they pipe us free frm rats or from mice,

If we've promised them aught, let us keep

our promise!
XV

Quite, Willy, as contas, caso exista

Alguma - ainda mais com um Flautista!

Se ele extinguir pragas como essas

Pra nós, cumpramos as promessas!

\section{REFERÊNCIAS BIBLIOGRÁFICAS}

BOASE-BEIER, Jean. Cerzido invisível: regras de um jogo. Ateliê Editorial. No prelo.

BOASE-BEIER, Jean; HOLMAN, Michael. (orgs) The Practices of Literary Translation: Constraints and Creativity. Londres: Routledge, 2016.

MILTON, John; VILLA, Dirceu (orgs.). Os escritos clássicos ingleses sobre a tradução 1615-1791. São Paulo: Humanitas/Capes, 2012.

PAZ, Otávio. O Arco e a Lira. Tradução de Olga Savary. Rio de Janeiro: Editora Nova Fronteira, 1982.

\footnotetext{
" Alípio Correia de FRANCA NETO - Doutor em Teoria Literária e Literatura Comparada (2011) pela Universidade em São Paulo. Graduado em Letras (2005) pela Universidade de São Paulo. Realizou estágio de pósdoutorado em Teorias da Tradução (2013) na Faculdade de Filosofia, Letras e Ciências Humanas. São Paulo, São Paulo, Brasil.

Dentre suas traduções poéticas, destacam-se: Pomas, um tostão cada, de James Joyce (Editora Iluminuras; Prêmio Jabuti de 2001); A Balada do Velho Marinheiro (Ateliê Editorial; Prêmio Jabuti de 2006); Vênus e Adônis (Editora Leya; Prêmio Jabuti em 2014); Eugênio Onêguin, de Alexandr Púchkin, em parceria com Elena Vássina (Ateliê Editorial); Menos enganados: 80 poemas de Philip Larkin; e os poemas em forma de livro $V$, A Sombra de Hiroshima e Um Jato Gélido, de Tony Harrison, todos a ser lançados este ano pela Ateliê Editorial.

Currículo acadêmico: http://lattes.cnpq.br/8887418945778576

ORCID: https://orcid.org/0000-0002-4011-3988

E-mail: alipiofranca@ig.com.br

${ }^{1}$ As edições, muitos distintas entre si, foram publicadas respectivamente pela Editora Musa e a Editora Iluminuras.

${ }^{2}$ Lembre-se, por exemplo, a poesia anglo-saxã, ou mesmo a poesia escrita em latim na época clássica, em que rimas não foram usadas, ou, quando foram, como no caso dos poemas das Carmina Burana, nunca apresentaram o nível de sofisticação técnica da poesia que não se valia delas.

${ }^{3}$ Um escritor ou crítico pode até reivindicar, por meio de categorias de valoração semelhantes, sua vinculação a um "movimento de vanguarda", mas, a rigor, sem uma "guarda" da qual ir à frente, de uma marcha da história a antecipar, inevitavelmente dará a impressão de estar usando a palavra "vanguarda" sem se lembrar de que ela é uma metáfora militar, tampouco de que sua arte acabará por ser mais um produto na prateleira. Na mesma linha de raciocínio, a objeção também poderia ser extensiva à típica necessidade dos modernistas, em sua articulação programática de teoria e práxis, de justificar o que faziam, como, por exemplo, sua suspicácia diante de rimas, ou a própria "liberdade" do verso livre: na grande era do pluralismo e do pragmatismo, tudo indica que, para "sensibilidade contemporânea", pós-moderna, o verso livre não precisa mais justificar sua liberdade, tampouco a poesia métrica e rimada, os "cerceamentos" que ela mesma se impõe, apologias tanto de uma coisa como da outra atualmente estando fadadas a soar questionáveis.
} 


\begin{abstract}
${ }^{4}$ No que tange a novas possibilidades do uso de rimas, amantes de poesia sempre se sentirão gratos, para citar um número mínimo de casos, pelas rimas consonânticas incidentais de Emily Dickinson e os padrões de assonância de Hopkins, inspirados no cynghanedd; as pararhymes de Wilfred Owen e as rimas silábicas de Auden, MacNeice e Keith Douglas; as rimas assonantes e as consonant chimes de Dylan Thomas e aos esquemas rímicos irregulares de Larkin, ou mesmo as formas rímicas, absorvidas de outras tradições, de Seamus Heaney.
\end{abstract}

${ }^{5}$ A incidência da rima numa longa tradição de poesia nonsense, sua perfeita adaptação a ela, se ligam a esse aspecto.

${ }^{6}$ Atribuímos sempre um valor antropológico positivo ao que consideramos uma "superação de obstáculos".

${ }^{7} \mathrm{Na}$ verdade, há escritores que demonstram trabalhar com a clara consciência de cerceamentos "auto-impostos", por assim dizer. Por exemplo, as palavras de Tony Harrison - a partir da Poética da Música de Stravinski - sobre sua própria escrita poética exprimem os mesmos pontos de vista expressos aqui: "Minha liberdade será tanto maior e mais significativa quanto mais estreitamente eu limitar meu campo de ação e mais eu me cercar de obstáculos. Tudo o que diminui limitações diminui a força". Fala transcrita de uma entrevista do poeta concedida a mim para minha edição de $V$.

${ }^{8}$ PAZ, Otávio. O Arco e a Lira. Tradução de Olga Savary. Rio de Janeiro: Editora Nova Fronteira, 1982, p. 192. Váléry exprimiu idêntica opinião ao afirmar que regras em alguns casos podem ter "qualidades criativas, sugerindo ideias que nunca teriam aflorado em sua ausência". VALERY, Paul. Discours sur l'ésthétique. Ouvres. Paris: Gallimard. v. I.

${ }^{9}$ Apenas para mencionar um exemplo familiar, o conceito de unidade, desde Platão e ligado em Aristóteles ao pensamento orgânico, ao longo dos tempos foi sempre um "cerceamento" imposto ao drama, no qual se manifestou como uma série de regras sobre tempo, lugar e ação. Desse ângulo, critérios de verossimilhança podem ser considerados cerceamentos, e todas as convenções poéticas, variando entre as culturas, são cerceamentos.

244 intencional.

${ }^{12}$ Uma seleção de ensaios da professora Jean Boasse-Beier, organizada e traduzida por mim, será lançada também pela Ateliê Editorial.

${ }^{13}$ Cerzido invisível: regras de um jogo, a ser lançado pela Ateliê Editorial.

${ }^{14}$ Tendo em vista que, de acordo com tal orientação, o tradutor deve levar em conta cerceamentos de ordem formal e linguística, convencional e poética, contextual e social, além dos impostos pela língua, cultura e público leitor, não há negar que a tradução envolve um fardo maior de cerceamento do que a escrita original, e que, paradoxalmente, são esses mesmos obstáculos que acabam por contribuir para o que se poderá considerar a "criatividade" do tradutor.

${ }^{15}$ Nas célebres palavras de Dryden, “[...] Em segundo lugar, há paráfrase, ou tradução com latitude, em que o autor é mantido ao alcance dos nossos olhos [...] porém suas palavras não são seguidas tão estritamente quanto seu sentido, que também pode ser ampliado, mas não alterado". MILTON, John; VILLA, Dirceu (orgs.). Os escritos clássicos ingleses sobre a tradução - 1615-1791. São Paulo: Humanitas/Capes, 2012. Diga-se que em meu livro, que articula prática tradutória e teoria, busco apresentar expedientes tradutórios resultando em soluções a cerceamentos que, sendo acréscimos semânticos relativamente ao original, podem ser considerados como ocorrendo dentro de "latitudes". 